\title{
AGRONOMIC AND ECONOMIC EFFICIENCY OF UREA TREATED WITH N-(n- butyl) thiophosphoric triamide APPLIED IN MAIZE CULTIVATION TOP-DRESSING
}

\author{
SOUZA, Everton Igor Severino ${ }^{1}$ \\ PIATI, Gabriel Luiz ${ }^{2}$ \\ OSÓRIO, Christian Rones Wruck de Souza ${ }^{3}$ \\ DE SOUZA, Hugo Manoel ${ }^{3}$ \\ DOS SANTOS, Osvaldir Feliciano ${ }^{4}$ \\ BARDIVIESSO, Diógenes Martins ${ }^{1}$
}

\begin{abstract}
SUMMARY - Addition of NBPT (N-(n-butyl) thiophosphoric triamide) to the urea granule has been one of the alternatives to increase nitrogen fertilizer efficiency, but there are still doubts about the stability of its treatment after storage and influence on culture yield. The objective was to evaluate the agronomic and economic efficiency of urea treated with NBPT in maize culture due to different rates of N. The test was conducted in the experimental area of Mato Grosso do Sul Federal University, Campus of Chapadão do Sul, MS, using the experimental design of randomized blocks in factorial $4 \times 3$, consisting of four rates $\left(0,60,120,180 \mathrm{Kg} \mathrm{ha}^{-1}\right)$ and three sources of nitrogen (convencional urea, urea + Just treated with NBPT, urea + NBPT treated and stored for a year) with four repetitions. The use of Just treated urea with NBPT for top-dressing in maize culture presented more productive and economic efficiency than using conventional urea. The rate of $180 \mathrm{~kg} \mathrm{ha}^{-1}$ of $\mathrm{N}$ applied in maize culture top-dressing has improved yield in $3,000 \mathrm{~kg} \mathrm{ha}^{-1}$ and may be used by conventional urea treated with NBPT.
\end{abstract}

Keywords: Nitrogen fertilizer, Urease inhibitor, Storage, Zea mays L.

\section{EFICIÊNCIA AGRONÔMICA E ECONÔMICA DE UREIA TRATADA COM N-(n-butil) tiofosfórico triamida APLICADA EM COBERTURA NA CULTURA DO MILHO}

\begin{abstract}
RESUMO - A adição de NBPT (N-(n-butil) tiofosfórico triamida) no grânulo de ureia tem sido uma das alternativas para aumentar a eficiência do fertilizante nitrogenado, porém ainda há dúvidas quanto à estabilidade do seu tratamento após o armazenamento e de sua influência sobre a produtividade das culturas. O objetivo do trabalho foi avaliar a eficiência agronômica e econômica da ureia tratada com NBPT na cultura do milho em função de diferentes doses de N. O ensaio foi conduzido na área experimental da Universidade Federal de Mato Grosso do Sul, Campus de Chapadão do Sul, MS, utilizando o delineamento experimental de blocos casualizados em fatorial 4x3, quatro doses $\left(0,60,120,180 \mathrm{Kg} \mathrm{ha}^{-1}\right)$ e três fontes de nitrogênio (ureia convencional, ureia + NBPT recém-tratada e ureia + NBPT tratada e armazenada há um ano) com quatro repetições. A utilização de ureia recém-tratada com NBPT para adubação de cobertura na cultura do milho apresentou maior eficiência produtiva e econômica que a utilização de ureia convencional. A dose de $180 \mathrm{~kg} \mathrm{ha}^{-1}$ de $\mathrm{N}$ aplicada em cobertura na cultura do milho cultivado no cerrado elevou a produtividade em $1.200 \mathrm{~kg} \mathrm{ha}^{-1}$ devendo ser adotada para ureia convencional e tratada com NBPT.
\end{abstract}

Palavras-chave: Fertilizante nitrogenado, Inibidor de urease, Armazenamento, Zea mays L.

\section{INTRODUCTION}

Maize hybrids available on the market have a constant evolution on yield and therefore increasing the need to use fertilizers (HIREL et al., 2007). Nitrogen fertilizers represent about

\footnotetext{
${ }^{1}$ State University of Mato Grosso do Sul, Cassilândia, MS, Brazil.

${ }^{2}$ Federal University of Grande Dourados, Dourados, MS, Brazil.

${ }^{3}$ Federal University of Mato Grosso do Sul, Chapadão do Sul, MS, Brazil.

${ }^{4}$ Paulista State University "Júlio de Mesquita Filho", Botucatu, SP, Brazil.
} 
$60 \%$ of the world fertilizer consumption, with a growing expectation in demand of $1.6 \%$ per year (FAO, 2015).

Nitrogen $(\mathrm{N})$ is one of the most required nutrients by maize culture, its deficiency is one of the limiting factors for the plant because it exercises functions in biochemical processes such as protein, enzyme, coenzyme, nucleic acid, fitocrom and chlorophyll constituents (FORNASIERI FILHO, 2007).

Urea is currently the most widely used nitrogen source, due to the lowest cost per unit of nitrogen and highest $\mathrm{N}$ concentration per granule (MALAVOLTA, 2006). Although urea is the most used source, its contained $\mathrm{N}$ is more susceptible to losses, comparing to other nitrogen fertilizers. The greatest losses of $\mathrm{N}$ from urea, occur mainly through its volatilization of amonia (WEZEl et al., 2014).

The volatilization of ammonia occurs during the hydrolysis of urea $\left(\mathrm{CO}\left(\mathrm{NH}_{2}\right)_{2}\right)$, which is performed by an enzyme present in the soil called urease, being this enzyme synthesized by microorganisms. After hydrolysis of urea, occurs the formation of carbonate $\left(\mathrm{CO}_{3}{ }^{2-}\right)$, ammonia $\left(\mathrm{NH}_{4}{ }^{+}\right)$and hydroxyl $\left(\mathrm{OH}^{-}\right) \cdot \mathrm{NH}_{4}{ }^{+}$when in basic $\mathrm{pH}$, tends to gain a proton and is converted into ammonia $\left(\mathrm{NH}_{3}\right)$, thus being lost to atmosphere in gaseous form (MARTINS, 2013).

Several modifications have been employed in relation to the urea granules for slowing its hydrolysis, aiming to reduce the $\mathrm{NH}_{3}$ volatization losses after its application on soil surface. One of them is the addition of inhibitors of the urea enzyme like NBPT (N-n-phosphorothioate butiltriamida) in the urea granule (GUIMARÃES et al., 2010).

Despite being a widely used source, there are still doubts about the stability of NBPT after its use in urea application, because usually maize producers do not use the full volume bought in, storing the rest for a later harvest. This work was conducted under the assumption that the stability of the addition of NBPT in urea granules after long periods of storage, may be reduced in relation to the newly treated one, decreasing the economic feasibility of the treatment.

The objective of this work aims to evaluate the agronomic and economic efficiency of urea treated with NBPT for maize culture in relation of different rates of N.

\section{MATERIAL AND METHOD}

The experiment was cultivated during the 2013/14 harvest in the experimental area of Federal University of Mato Grosso do Sul, located in Chapadão do Sul county, MS, under the following coordinates: Lat. $18^{\circ} 47^{\prime} 39^{\prime \prime}$ S, Long 24.38 . 52 $37^{\circ} 23^{\prime \prime}$ and of 820 meters. 
The region's climate is classified as tropical humid, with a dry winter and rainy summer, average temperature between 13 and $28{ }^{\circ} \mathrm{C}$ and an annual average pluvial precipitation 1,850 mm (CUNHA et al., 2013). The climate data of experiment conducting period can be observed at figure 1 .

Figure 1 - Pluvial precipitation $(\mathrm{mm})$, average temperature $\left({ }^{\circ} \mathrm{C}\right)$ and relative humidity $(\%)$ per day during the period of conducting the experiment.

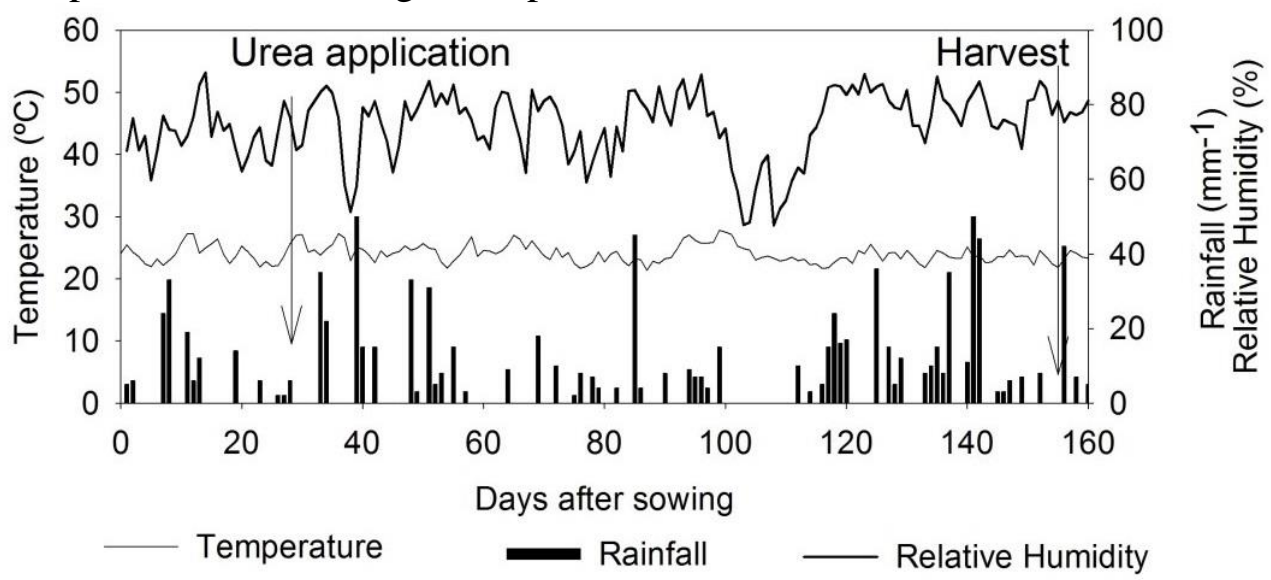

Source: Prepared by Author

The local soil texture was classified as red clay Latosol, according to the classification of Santos et al., (2013). Showing particle size of sand 49\%, 7\% silt and 44\% clay at a depth of 0-0.2 $\mathrm{m}$. The results of the chemical analysis $0-20 \mathrm{~cm}$ of the soil at were $\mathrm{pH}=4.81 \mathrm{CaCl}_{2}$; Organic matter= 19,23; $\mathrm{P}\left(\right.$ Mehlich 1) = 5,51 mg. $\mathrm{dm}^{-3} ; \mathrm{K}=0.21 ; \mathrm{Ca}=1,54 ; \mathrm{Mg}=0,65 ; \mathrm{H}+\mathrm{Al}=5,4$ cmols. $\mathrm{dm}^{-3} ; \mathrm{CEC}=8,24 \%$.

The sowing of maize culture was made on 11/8/2013, and the come up took place on 5 Days after sowing (DAS). Simple, early cycled AG 7098 VT PRO 2 hybrid seeds were used. Maize was sown at $0.45 \mathrm{~m}$ between rows and spacing and sowing density was 65000 plants per hectare. The maize was handled and conducted similar to "non-irrigated" condition and under notill system, with previous culture of soybeans grown in "summer" crop and Crotalaria spectabilis in "autumn-winter intercropping systems. The fertilization followed the recommendations of Sousa and Lobato (2004) and being the same for all treatments. At sowing were applied $300 \mathrm{~kg}$ $\mathrm{ha}^{-1}$ of $6 / 24 / 14+$ Micro in furrows and $90 \mathrm{~kg} \mathrm{ha}^{-1}$ of $\mathrm{K}_{2} \mathrm{O}$ for top-dressing.

The experimental design used were randomized blocks, with 12 treatments and four replications, amounting 48 plots. Each plot was 5 meters long and 3.15 wide (7 rows of cultivation spaced at $0.45 \mathrm{~m}$ ). In a $3 \times 4$ factorial scheme treatments consisted in the application of urea + newly treated NBPT, urea + NBPT treated and stored for a year and simple 
conventional urea. The three sources of urea were tested in four rates of nitrogen, being 0,60 , 120 and $180 \mathrm{~kg} \mathrm{ha}^{-1}$.

For determining the urea treatment held a year ago was made the mixture of urea + NBPT on 11/26/2012 by Southwest Fertilizers company, being stored in bags afterwards on wooden pallets of $10 \mathrm{~cm}$ from the ground, inside a hangar with room temperature, until the date of treatment applications. The NBPT used was UREMAX NBPT® from the company Adfert Ltda.

Fertilizers were applied manually and broadcasted without incorporation when plants had four fully expanded leaves (phenological stages V4). Aproximate 30 days after DAS.

The female maize flowering occurred at 80 DAS, moment in which the samples for foliar analysis of nitrogen were realized. At this time was collected the central third of five leaves in the useable area of each plot. The opposite leaf and below the main cob was colected, as recommended by Malavolta (1997). For laboratory tests the samples were properly washed and dried in an oven, after drying the central nerves of the leaves were removed and then grinded.

The evaluations of the green color intensity of the leaves (indirect measurement of chlorophyll) were held on the occasion of the female flourishing, being measured with the aid of a ClorofiLOG ${ }^{\circledR}$ CFL chlorophyllmeter model 1030, which expressed the results in an index called FCI: Falker Chlorophyll index , sends light in wavelengths of 635; 660 and $880 \mathrm{~nm}$ (FALKER, 2008). At data reading, the unit was positioned between the edge and the central third nerve of the opposite leaf and below the first cob in five plants in the useable area.

Biometric aspects have been evaluated at the time of harvest on 155 DAS, being determined by the measurement of the height of insertion of the first cob and the maize stem diameter. The height of cob insertion was determined by the distance between the soil surface and the first cob insertion point with the stem, being used a scale measuring tape. The average stem diameter, was measured with the aid of a caliper, at the second internode from the base of five plants in the useable area.

After the cob harvest of the useable area, the following evaluations were conducted : cob diameter, carried out with the aid of a digital caliper, measuring the diameter of the cob's central part; number of rows per cob, determined by counting the total number of rows in five cobs chosen randomly by repetition; grains per row, determined by the average count of the number of grains in five rows selected randomly per cob; and grain Yield made by weighing the grain harvested in the area of each plot, being the mass corrected by $13 \%$ humidity and the values converted to $\mathrm{kg} \mathrm{ha}^{-1}$. 
Resulting data were submitted to analysis of variance, where, for the factors of quantitative nature, a regression analysis was made, and for the factors of qualitative character was realized the Tukey test ( $\mathrm{p}<0.05)$, with the aid of SISVAR computer system .

For economic analysis was used the Total Operating Cost (TOC) structure from the Instituto de Economia Agrícola (IEA), proposed by Matsunagaet al (1976), with some adjustments for the agricultural system in the region. TOC consists by the direct expenses (effective operating cost EOC) plus indirect expenses (depreciation of durable goods and social charges). The EOC was composed by mechanized operations and inputs. For indirect expenses was considered the EOC rate of 5\%. Interest costs were obtained considering the rate of $5.5 \%$ per year on $50 \%$ of EOC.

In fact this work was done as a simulation where each treatment of the experiments represented commercial crops. The data and values of mechanized operations, inputs, such as fertilizers, chemical pesticides, seeds and seed treatment, were obtained from associated farmers of Fundação de Apoio a Pesquisa Agropecuária of Chapadão do Sul.

The average prices of inputs were collected in the region of Chapadão do Sul, MS with average values originated from the first semester/2016. The average value of a bushel of maize for the State of Mato grosso do Sul in the first half year was $\$ 9.45$ per unit produced. The value of the dollar used for economic analysis was $\mathrm{R} \$ 3.69$ (average of the dollar in the first semester/2016). Nevertheless in relation to sources of $\mathrm{N}$, the amount paid by the farmer was $\$$ 338.00 and $\$ 379.00$ per tonne for urea and Urea + NBPT respectively.

\section{RESULT AND DISCUSSION}

There was only interaction between rates and sources for the variable yield. In relation to rates, difference was observed between green color index and stem diameter (Table 1).

Table 1 - Analysis of variance for nitrogen accumulation in the leaf (NL), intensity of green color of the leaf (IGC), diameter of stem base (DS) height of insertion of the main cob (HIC), cob diameter (CD), number of grains per row (GR), number of rows per cob (NRC) and maize yield. Chapadão do Sul, MS, UFMS-CPCS, 2013 - 2014 harvest.

\begin{tabular}{cccccccccc}
\hline \multirow{2}{*}{ FV } & \multirow{2}{*}{ GL } & NL & IGC & DS & HIC & CD & GR & NRC & Yield \\
\cline { 3 - 9 } Block & 3 & 3.09 & 3.89 & 0.08 & 0.004 & 1.55 & 14.30 & 0.95 & 149493.17 \\
Source (S) & 2 & 24.62 & 8.97 & 0.02 & 0.0009 & 0,70 & 1.18 & 0.71 & $507826.64 * *$ \\
Rates (R) & 3 & 8.81 & $35.20^{* *}$ & $0.15^{* *}$ & 0.006 & 2.11 & 6.62 & 2.41 & $24121286.71 * *$ \\
S x R & 6 & 11.32 & 1.31 & 0.007 & 0.0004 & 1.04 & 0.78 & 1.40 & $391365.19^{* *}$ \\
Error & 36 & 32.09 & 4.14 & 0.02 & 0.003 & 1.02 & 6.93 & 1.36 & 85078.28 \\
\hline CV (\%) & 18.73 & 3.55 & 7.01 & 3.68 & 1.98 & 7.46 & 6.89 & 2.52 \\
Average & 30.24 & 57.30 & 2.16 & 1.56 & 51.05 & 35.31 & 16.94 & 11564.69 \\
\hline$* *$ significant at 1\% probability by the F-test. & & & & & & \\
\hline
\end{tabular}


The results observed in the green color intensity of leaves (GCI) were not influenced by the used sources (Table 1), however, the increased rate of $\mathrm{N}$ resulted in larger data readings of the GCI (Figure 2), highlighting the importance of this nutrient in the constitution of chlorophyll, compound responsible for the green color (Figure 2). The elevation of the GCI in the leaves is because the concentration of this pigment being related to the content of $\mathrm{N}$ in the plant. So 50 to $70 \%$ of $\mathrm{N}$ total of the leaves is an integral part of enzymes that are related to the chloroplasts. Thus, the greater absorption of nitrogen by plants, reflects increase in green color intensity of leaves.

Figure 2 - Intensity of green color of maize leaves, due to the application of nitrogen rates. Chapadão do Sul, MS, UFMS-CPCS, 2013 - 2014 harvest.

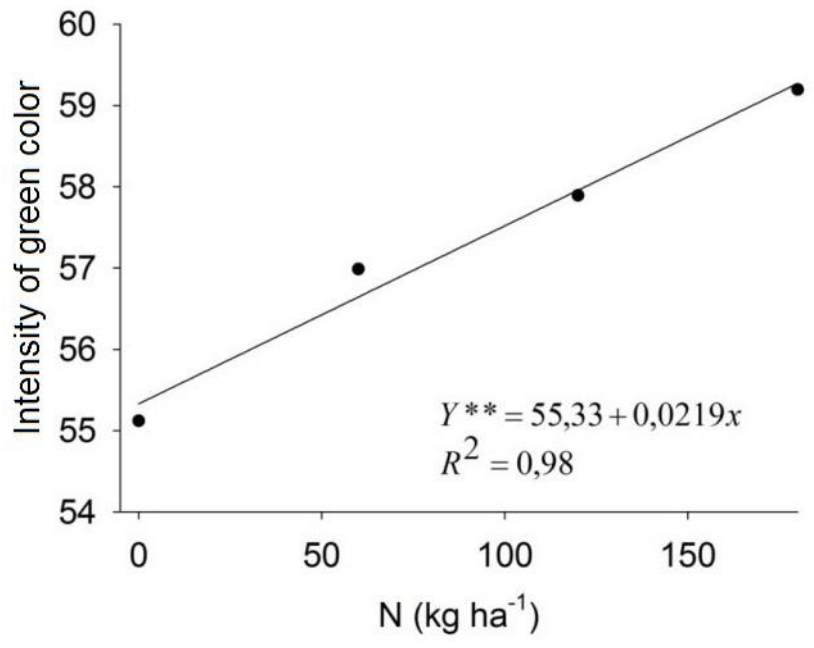

Source: Prepared by Author

Similar results of this work were found by Jakelaitiset al. (2005), which observed positive linear effect between the intensity of green coloring and the rates of $\mathrm{N}$. This effect can be noticed by photosynthesis increase, as well as smaller fluorescence, that may indicate a higher chloroplast amount in leaves, raising the efficiency of photosynthesis (AKRAMEt al., 2011).

In relation to polynomial model DS increased with the provision of $\mathrm{N}$ until the rate of 114 $\mathrm{kg} \mathrm{ha}{ }^{-1}$, and after this dosage application of $\mathrm{N}$ provided decrease in stem diameter of plants (Figure 3). The stem is a important structure for achieving yield gains because it has storage capacity of soluble solids, which later will be used for grain formation (FANCELLI; GOLD NETTO 2000). So, larger stem diameters usually correlate positively with higher yields of grains (SORATTO et al., 2010), a fact not proven in our present results. 
Figure 3 - Regression model adjusted for stem diameter, due to the application of rates of nitrogen on maize. Chapadão do Sul, MS, UFMS-CPCS, 2013 - 2014 harvest.

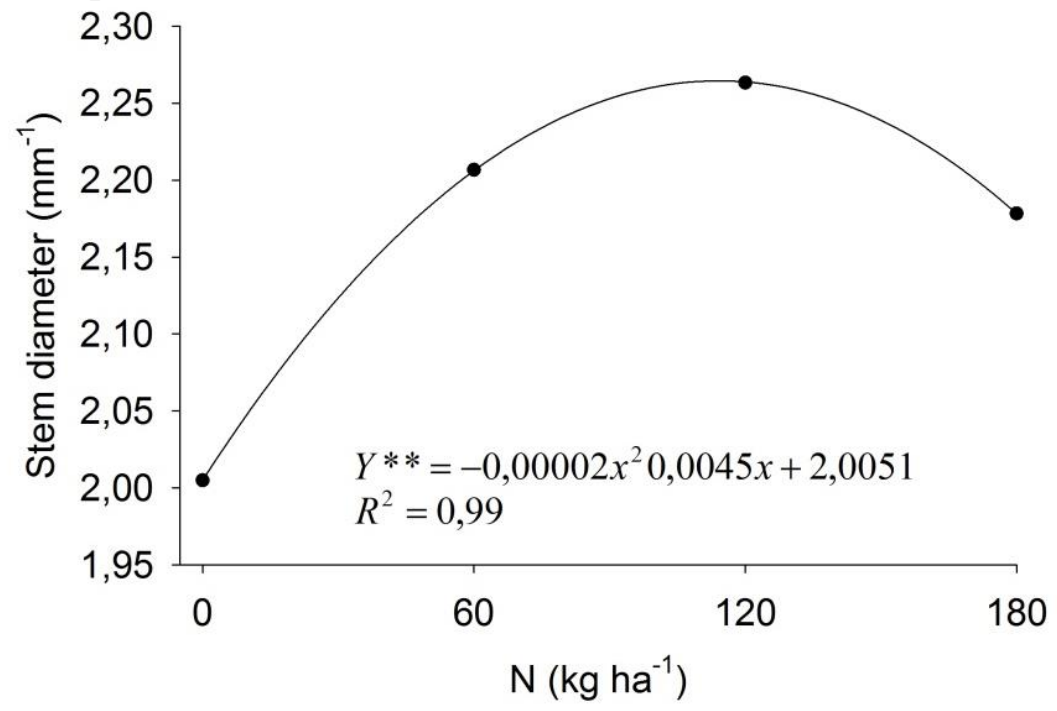

Source: Prepared by Author

Goes et al., (2013) also found a quadratic effect in relation to stem diameters when maize was submitted to rates of $\mathrm{N}$ being the amount of $84.4 \mathrm{~kg} \mathrm{~N}^{-1}$ the point of diameter maximums. However different results in relation to this work were found by Mendez et al. (2013) where linear effects were found by rates of nitrogen, resulting in larger diameters of stems with maximum rates of $\mathrm{N}$, even when associated with higher plant density.

The treatment of urea with NBPT provided larger yield for maize culture, being the Just treated one the owner of greater yield $\left(11,707 \mathrm{~kg} \mathrm{ha}^{-1}\right)$. Similar results were found by Silva et al. (2011), where the largest rates of urea treated with NBPT provided greater yield of maize. These yield increases have also been recorded in other crops such as cotton (KAWAKAMI et al., 2012), wheat (GRANT, 2014; O'DONOVAN et al., 2008).

The use of urea treated with NBPT as nitrogen source for the culture of maize can result in production increases due to the reduction of losses of $\mathrm{N}$ by volatilization of NH3 (FRAZÃO et al., 2014). However, Meira et al. (2009) noted in his work that the losses by volatilization of $\mathrm{NH} 3$, between several nitrogen fertilizers including urea not reflected in maize yield.

Newly treated urea with NBPT showed no statistical difference in relation to urea stored for a year. Urea treatments with NBPT stored for a year tended to yield losses. Urea stability with NBPT treatment presents a long half life of approximately 10 weeks, when stored at $25^{\circ} \mathrm{C}$ (WATSON et al., 2008).

Storage conditions studied by Watson et al., (2008) are similar to the conditions found in storage sheds where urea underwent treatment, which probably could have reduced the efficiency 
of the inhibitor in reducing volatilization of $\mathrm{NH} 3$, affecting the availability of $\mathrm{N}$ for the plant and therefore yield.

Regardless of the used source increasing rates of nitrogen provided increased yield, (Figure 4). Nitrogen is one of the limiting factors in plants, because it exercises functions in biochemical processes such as a constituent of proteins, enzymes, coenzymes, nucleic acids, Phytochrome and chlorophyll, and is considered extremely necessary for the proper performance of maize cultivation (FORNASIERI FILHO, 2007).

Figure 4 - Regression model adjusted for maize yield, due to the application of nitrogen rates. CU-conventional urea; NTU- newly treated urea; URY-urea treated a year ago. Chapadão do Sul, MS, UFMS-CPCS, 2013 - 2014 harvest.

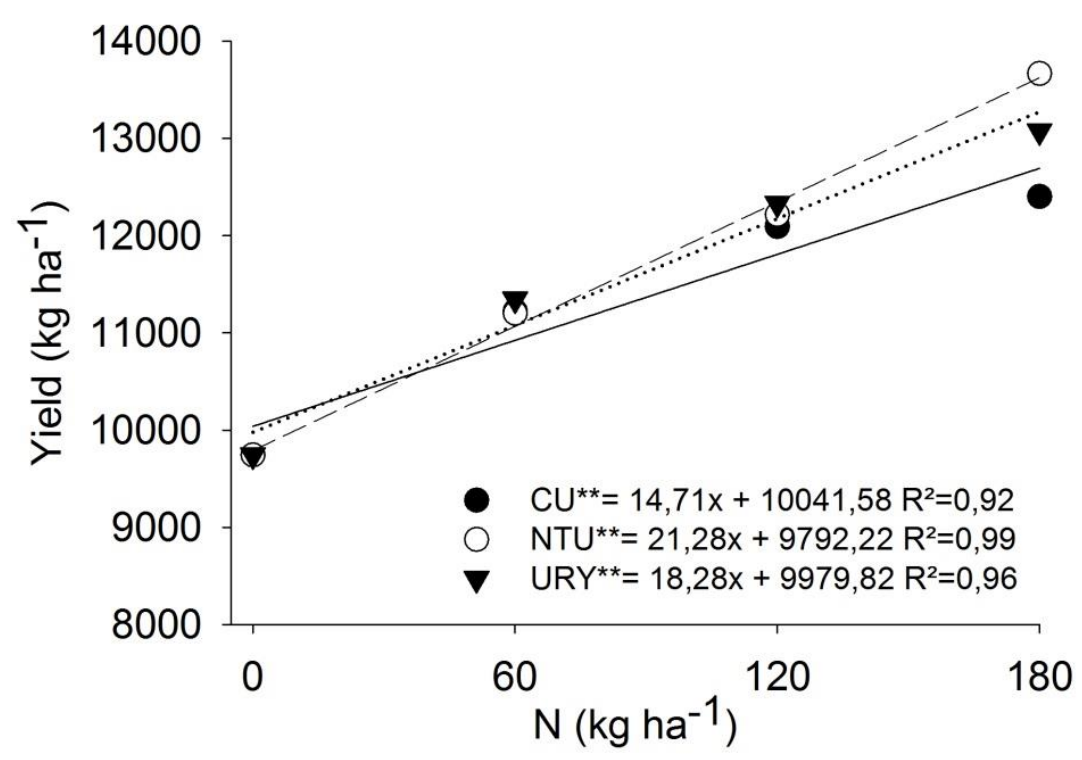

Source: Prepared by Author

Silva et al., (2011) observed similar results to those found by this work, where it was not possible to establish a maximum grain yield. Santos et al., (2013), working with rates of nitrogen for high yields found maximum yield $\left(14,552 \mathrm{~kg} \mathrm{ha}^{-1}\right)$ at $316 \mathrm{~kg}$ of $\mathrm{N} \mathrm{ha}^{-1}$, being the rate of economic efficiency $228 \mathrm{~kg} \mathrm{ha}^{-1}$ with yield of 14,279 $\mathrm{kg} \mathrm{ha}^{-1}$. However Okumura (2013) obtained better fit in a quadratic model, being obtained maximum yield with $145 \mathrm{~kg} \mathrm{ha}^{-1}$ of $\mathrm{N}$. Demonstrating the high responses of this culture to nitrogen.

The average estimated maize yield in this work, in all treatments, were above the national average, including the control treatment without $\mathrm{N}$ top dressing application, $9,748.57 \mathrm{~kg} \mathrm{ha}^{-1}$ (Figure 4). This high yield in Chapadão do Sul-MS region has been obtained by the use of highyielding hybrids together soil and climatic conditions of the region, besides addition to rotation 
system adoption of maize and soybeans in summer and growing green manure in autumn-winter period.

Despite the cultivation of maize in the summer after crotalaria in autumn-winter and soybeans previously, it responds to high rates of $\mathrm{N}$ in top dressing $\left(180 \mathrm{~kg} \mathrm{~N} \mathrm{ha}^{-1}\right)$ and urea treated with urease inhibitor NBPT. Agreeing to recommendations of Souza and Lobato (2004) suggesting the need for application of $180 \mathrm{~kg}$ of $\mathrm{N} \mathrm{ha}^{-1}$ in top dressing of maize culture grown in the " cerrado" for $12,000 \mathrm{~kg} \mathrm{ha}^{-1}$ of grain yield.

The use of high rates of $\mathrm{P}$ and $\mathrm{K}$, applied as a basic fertilizer, can provide a better use of $\mathrm{N}$ present in the soil, originated from application or through organic matter (Queiroz et al., 2011).

Table 2 contains the economic analysis considering the sources and amount of nitrogen with the values relating to mechanized operations and inputs that were necessary during the maize cultivation.

Table 2 - Mechanized operation cost and the inputs used in the maize "first harvest" grown in Chapadão do Sul-MS, 2015/16 harvest.

(Continua)

\begin{tabular}{lllll}
\hline Processes and inputs & Unit & $\begin{array}{l}\text { Quantity } \\
\mathbf{h a}^{-1}\end{array}$ & $\begin{array}{l}\text { Value } \\
\text { Unit. } \mathbf{( \$ )}\end{array}$ & $\begin{array}{c}\text { Total } \\
\mathbf{h a}^{-1} \mathbf{( \$ )}\end{array}$ \\
\hline A. Mechanized operations & - & - & - & 81.79 \\
\hline A.1 Sowing and fertilization & $\mathrm{hm}$ & 0.38 & 43.77 & 16.63 \\
\hline A.2 Spraying & $\mathrm{hm}$ & 0.29 & 24.23 & 7.03 \\
\hline A.3 Harvest & $\mathrm{hm}$ & 0.67 & 43.45 & 29.11 \\
\hline A.4 Grain transportation & $\$ \mathrm{t}-1$ & 3.60 & 4.00 & 14.39 \\
\hline A.5 Receiving/drying/cleaning & $\$ \mathrm{t}-1$ & 3.60 & 4.07 & 14.63 \\
\hline B. Inputs & - & - & - & 477.31 \\
\hline B.1 Seeds and treatment & - & - & - & 140.37 \\
\hline B.1.1 AG 7098 VT PRO 2 & $\mathrm{kg}$ & 20.00 & 6.22 & 124.34 \\
\hline B.1.2 Imidacloprid + Thiodicarb & $\mathrm{L}$ & 0.30 & 53.23 & 15.97 \\
\hline B.1.3 Graphite & $\mathrm{kg}$ & 0.10 & 0.66 & 0.07 \\
\hline B.2 sowing fertilization & - & - & - & 207.72 \\
\hline B.2.1 06-24-14 + Micro & $\mathrm{t}$ & 0.30 & 482.38 & 144.72 \\
\hline B.2.2 KCl & $\mathrm{t}$ & 0.15 & 420.05 & 63.01 \\
\hline
\end{tabular}


Table 2 - Mechanized operation cost and the inputs used in the maize "first harvest" grown in Chapadão do Sul-MS, 2015/16 harvest.

\begin{tabular}{|c|c|c|c|c|}
\hline Processes and inputs & Unit & $\begin{array}{l}\text { Quantity } \\
\text { ha }^{-1}\end{array}$ & $\begin{array}{l}\text { Value } \\
\text { Unit. (\$) }\end{array}$ & $\begin{array}{l}\text { Total } \\
\text { ha }^{-1}(\$)\end{array}$ \\
\hline B.3 Herbicides & - & - & - & 83.20 \\
\hline B.3.1 Glyphosate & $\mathrm{kg}$ & 4.00 & 7.71 & 30.84 \\
\hline B.3.2 Carfentrazona-ethilic & $\mathrm{L}$ & 0.05 & 86.50 & 4.33 \\
\hline B.3.3 Atrazine & $\mathrm{L}$ & 3.00 & 6.18 & 18.54 \\
\hline B.3.4 Tembotrione & $\mathrm{L}$ & 0.24 & 117.07 & 28.10 \\
\hline B.3.5 Mineral Oil & $\mathrm{L}$ & 0.60 & 2.33 & 1.40 \\
\hline B.4 Insecticides & - & - & - & 20.70 \\
\hline B.4.1Lambda-cialotrina+Tiametoxam & $\mathrm{L}$ & 0.25 & 35.34 & 17.67 \\
\hline B.4.2 Mineral Oil & $\mathrm{L}$ & 0.65 & 2.33 & 3.03 \\
\hline B.5 Fungicides & - & - & - & 25.32 \\
\hline B.5.1Azoxystrobin+Cyproconazole & $\mathrm{L}$ & 0.30 & 37.54 & 22.52 \\
\hline B.5.2 Mineral Oil & $\mathrm{L}$ & 0.60 & 2.33 & 2.80 \\
\hline \multicolumn{5}{|l|}{ C. Nitrogen fertilization (Treatments) } \\
\hline \multicolumn{5}{|l|}{ C.1 Convencional rate of urea } \\
\hline C.1.1 Zero & - & - & - & 0.00 \\
\hline C.1.2 60 & $\mathrm{t}$ & 0.133 & 338.75 & 45.05 \\
\hline C.1.3 120 & $\mathrm{t}$ & 0.266 & 338.75 & 90.10 \\
\hline C.1.4 180 & $\mathrm{t}$ & 0.399 & 338.75 & 135.15 \\
\hline \multicolumn{5}{|l|}{ C. 2 Rate of urea+NBPT } \\
\hline C.2.1 60 & $\mathrm{t}$ & 0.133 & 379.40 & 50.46 \\
\hline C.2.2 120 & $\mathrm{t}$ & 0.266 & 379.40 & 100.92 \\
\hline C.2.3 180 & $\mathrm{t}$ & 0.399 & 379.40 & 151.40 \\
\hline
\end{tabular}

Source: Fundação de Apoio a Pesquisa Agropecuária de Chapadão. Agricultural year of 2015/16.

Urea treated with NBPT provided greater gross revenue per hectare compared to the conventional urea, with linear response, providing an increase of $\$ 78.52$ due to extra rates. On 
the other hand, NBPT treated urea presents higher total operating costs (HOC), however provided greater profits (Table 3).

Table 3 - Economic analysis of rates and sources of nitrogen applied broadcasted superficially, yield in gross revenue, effective operating cost (EOC), total operating cost (TOC), profit, relationship between the amount received and the value of investment (Rec/Invest), 2013/2014 harvest in Chapadão do Sul-MS.

\begin{tabular}{|c|c|c|c|c|c|c|c|}
\hline \multirow[t]{2}{*}{ N Source } & Rate & Yield & $\begin{array}{c}\text { Gross } \\
\text { income }\end{array}$ & EOC & TOC & Profit & \multirow[t]{2}{*}{$\begin{array}{c}\text { Rec/ } \\
\text { Invest }\end{array}$} \\
\hline & \multicolumn{2}{|c|}{---- $\mathrm{Kg} \mathrm{ha}^{-1}$---- } & \multicolumn{4}{|c|}{ 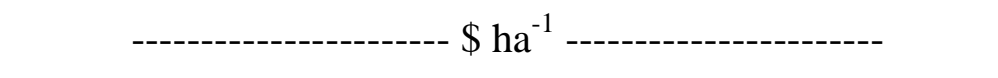 } & \\
\hline \multirow{4}{*}{ Urea } & 0 & $10,041.58$ & 617.55 & 559.11 & 602.44 & 15.12 & 1.03 \\
\hline & 60 & $10,924.18$ & 671.83 & 580.84 & 625.85 & 45.98 & 1.07 \\
\hline & 120 & $11,806.7$ & 726.11 & 601.16 & 647.74 & 78.37 & 1.12 \\
\hline & 180 & $12,689.38$ & 780.39 & 621.49 & 669.65 & 110.74 & 1.17 \\
\hline \multirow{2}{*}{ Urea+ } & 0 & $9,792.22$ & 602.22 & 559.11 & 602.44 & -0.22 & 1.00 \\
\hline & 60 & $11,069.02$ & 680.74 & 583.27 & 628.47 & 52.27 & 1.08 \\
\hline \multirow[t]{2}{*}{ NBPT } & 120 & $12,345.82$ & 759.26 & 606.04 & 653.00 & 106.26 & 1.16 \\
\hline & 180 & $13,622.62$ & 837.79 & 628.80 & 677.53 & 160.26 & 1.24 \\
\hline
\end{tabular}

The two nitrogen sources provided a linear profit increase with increased rates. NBPT urea presented higher profit than the conventional urea at all rates, and rate $180 \mathrm{~kg} \mathrm{ha}^{-1}$ holds the greatest profitability.

The results obtained in this study corroborate with Silva et al., (2011), who researching the use of urea treated with NBPT in rates of $60,120,180$ and $240 \mathrm{~kg} \mathrm{ha}^{-1}$ of $\mathrm{N}$, found that the

biggest profit margin was obtained by the treatment with $180 \mathrm{~kg} \mathrm{ha}^{-1}$.

The relationship between the amount received and the value of the investment (Rec/Invest) both with NBPT treated urea as for conventional urea the highest Rec/Invest was provided by a rate of $180 \mathrm{~kg} \mathrm{ha}^{-1}$ of $\mathrm{N}$. So, for urea + NBPT every one dollar (\$1.00) invested returned one dollar and twenty-four cents (\$1.24) and for conventional urea one dollar seventeen cents $(\$ 1.17)$.

\section{CONCLUSION}

The use of newly NBPT treated urea, for top-dressing in maize cultivation presents bigger yield and the economic efficiency than the conventional use of urea.

The rate of $180 \mathrm{~kg} \mathrm{ha}^{-1}$ of $\mathrm{N}$ applied in top-dressing on maize grown in the "cerrado" provides a yield exceeding $12,000 \mathrm{~kg} \mathrm{ha}^{-1}$ and should be adopted for conventional and NBPT treated urea. 
Urea treated with NBPT and stored for a period of one year presents reduction in efficiency compared to urea that received this treatment recently.

\section{REFERENCES}

AKRAM, M.; ASHRAF, M.; JAMIL M.; IQBAL, R. M.; NAFEES, M.; KHAN, M. A. Nitrogen application improves gas exchange characteristics and chlorophyll fluorescence in maize hybrids under salinity conditions. Russian Journal of Plant Physiology, v. 58, n. 3, p. 394-401, 2011. DOI: $10.1134 /$ S1021443711030022.

CUNHA, F. F.; MAGALHÃES, F. F.; CASTRO, M. A. Métodos para estimativa da evapotranspiração de referência para Chapadão do Sul, MS. Engenharia na Agricultura, v. 21, n. 2, p. 159-172, 2013. DOI: 10.13083/1414-3984.v21n02a06.

FALKER. Manual do medidor eletrônico de clorofila ClorofiLOG CFL 1030, p. 1-4, 2008.

FANCELLI, A. L.; DOURADO NETO, D. Produção de Milho. Guaíba: Agropecuária, 2000. 360p.

FORNASIERI FILHO, D. Manual da cultura do milho. Jaboticabal: Funep, 2007. 576p.

GOES, R. J.; RODRIGUES, R. A. F.; TAKASU, A. T.; ARF, O. Características agronômicas e produtividade do milho sob fontes e rates de nitrogênio em cobertura no inverno. Revista Brasileira de Milho e Sorgo, v. 12, n. 3, p. 250-259, 2013. DOI: 10.18512/1980-

6477/rbms.v12n3p250-259.

GUIMARÃES, G. G. F.; PALVA, D. M.; RENA, F. C.; SOUZA, H. N.; PEREIRA, C. G.; CANTARUTTI, R. B. Volatilização de amônia pela hidrólise da ureia com diferentes formas de acabamento. Informações Agronômicas, n. 131, p. 17-18, 2010.

JAKELAITIS, A.; SILVA, A. A.; FERREIRA, L. R. Efeitos do nitrogênio sobre o milho cultivado em consórcio com Brachiaria brizantha. Acta Scientiarum. v. 27, n. 1, p. 39-46, 2005. (2005). DOI: 10.4025/actasciagron.v27i1.1916.

MARTINS, A. G. Fatores de sucesso no manejo nutricional do cafeeiro. Informações Agronômicas, n. 114, p. 1-12, 2013.

MALAVOLTA, E. Manual de nutrição mineral de plantas. São Paulo: Ceres, 2006. 638 p.

MALAVOLTA, E.; VITTI, G. C.; OLIVEIRA, S. A. Avaliação do estado nutricional das plantas: princípios e aplicações. Piracicaba: Potafos, 1997. 319 p.

MATSUNAGA, M.; BEMELMANS, P. F.; TOLEDO, P. E. N.; DULLEY, R. D.; OKAWA, H.; PEDROSO, I. A. Metodologia do custo de produção utilizada pelo IEA. Agricultura em São Paulo, v. 23, p. 123-139, 1976.

MEIRA, F. A.; BUZETTI, S.; ANDREOTTI, M.; ARF, O.; SÁ, M. E., ANDRADE, J. A. C. Fontes e épocas de aplicação do nitrogênio na cultura do milho irrigado. Semina: Ciências Agrárias, v. 30, n. 2, p. 275-284, 2009. DOI: 10.5433/1679-0359.2009v30n2p275. 
MENDEZ, M. C.; MATCHULA, P. H.; ROSSI, E. S.; OLIVEIRA, B. R.; SILVA, C. A.; SÉKULA, C. R. Adubação nitrogenada em cobertura associada com densidades populacionais de híbridos de milho em espaçamento reduzido. Revista Brasileira de Milho e Sorgo, v. 12, n. 2, p. 92-101, 2013. DOI: 10.18512/1980-6477/rbms.v12n2p92-101.

O’DONOVAN, J. T.; CLAYTON, G. W.; GRANT, C. A.; HARKER, K. N.; KELLY, T. T.; LUPWAYI, N. Z. Effect of nitrogen rate and placement and seeding rate on barley Yield and wild oat fecundity in a zero tillage system. Crop Science, v. 48, n. 4, p. 1569-1574, 2008. DOI: 10.2135/cropsci2007.10.0587.

OKUMURA, R. S.; YANO, G. T.; MARIANO, D. C.; ZACCHEO, P. V. C.; TAKAHASHI, H. W. Nutrição nitrogenada no milho fertilizado com ureia tratada com inibidor de urease. Semina: Ciências Agrárias, v. 34, n. 1, p. 157-170, 2013. DOI: 10.5433/1679-0359.2013v34n1p157.

QUEIROZ, A. M.; SOUZA, C. H. E.; MACHADO, V. J.; LANA, R. M. Q.; KORNDORFER, G. H.; SILVA, A. A. Avaliação de diferentes fontes e rates de nitrogênio na adubação da cultura do milho (Zea mays L.). Revista Brasileira de Milho e Sorgo, v. 10, n. 3, p. 257-266, 2011. DOI: 10.18512/1980-6477/rbms.v10n3p257-266.

SANTOS, H. G.; JACOMINE, P. K. T.; ANJOS, L. H. C.; OLIVEIRA, V. A.; LUMBRERAS, J. F.; COELHO, M. R.; ALMEIDA, J. A.; CUNHA, T. J. F.; OLIVEIRA, J. B. Sistema brasileiro de classificação de solos. 3.ed. Brasília, 2013. 353p.

SANTOS, L. P. D.; AQUINO, L. A.; NUNES, P. H. M. P.; XAVIER, F. O. Doses de nitrogênio na cultura do milho para altas produtividades de grãos. Revista Brasileira de Milho e Sorgo, v. 12, n. 3, p. 270-279, 2013. DOI: 10.18512/1980-6477/rbms.v12n3p270-279.

SILVA, D. R. G.; PEREIRA, A. F.; DOURADO, R. L.; SILVA, F. P.; ÁVILA, F. W.; FAQUIN, V. Productivity and efficiency of nitrogen fertilization in maize under different levels of urea and NBPT-treated urea. Ciência e Agrotecnologia, v. 35, n. 3, p. 516-523, 2011. DOI:

10.1590/S1413-70542011000300012.

SORATTO, R. P.; PEREIRA, M.; COSTA, T. A. M.; LAMPERT, V. N. Fontes alternativas e rates de nitrogênio no milho safrinha em sucessão à soja. Revista Ciência Agronômica, v. 41, n. 4, p. 511-518, 2010. DOI: 10.1590/S1806-66902010000400002.

SOUSA, D. M. G.; LOBATO, E. (Ed.). Cerrado: correção do solo e adubação 2. ed. Brasília, DF: Embrapa Informação Tecnológica, 2004. 416 p.

WATSON, C. J.; AKHONZADA, N. A.; HAMILTON, J. T. G.; MATTHEWS, D. I. Rate and mode of application of the urease inhibitor $\mathrm{N}$-(n-butyl) thiophosphoric triamide on ammonia volatilization from surface-applied urea. Soil Use and Management, v. 24, n. 3, p. 246-253, 2008. DOI: $10.1111 / \mathrm{j} .1475-2743.2008 .00157 . x$. 